\title{
Igenerations' Intention to become Entrepreneur: Determinants in Malaysia
}

Melissa Wee, Nur Rabiatul Adawiyah, Mohd Zaki Sadik, Nor Lelawati Jamaluddin

To Link this Article: http://dx.doi.org/10.6007/IJARBSS/v11-i6/10207

DOI:10.6007/IJARBSS/v11-i6/10207

Received: 16 April 2021, Revised: 19 May 2021, Accepted: 02 June 2021

Published Online: 18 June 2021

In-Text Citation: (Wee et al., 2021)

To Cite this Article: Wee, M., Adawiyah, N. R., Sadik, M. Z., \& Jamaluddin, N. L. (2021). Igenerations' Intention to become Entrepreneur: Determinants in Malaysia. International Journal of Academic Research in Business and Social Sciences, 11(6), 780-792.

Copyright: (c) 2021 The Author(s)

Published by Human Resource Management Academic Research Society (www.hrmars.com)

This article is published under the Creative Commons Attribution (CC BY 4.0) license. Anyone may reproduce, distribute, translate and create derivative works of this article (for both commercial and non-commercial purposes), subject to full attribution to the original publication and authors. The full terms of this license may be seen

at: http://creativecommons.org/licences/by/4.0/legalcode

Vol. 11, No. 6, 2021, Pg. 780- 792

Full Terms \& Conditions of access and use can be found at http://hrmars.com/index.php/pages/detail/publication-ethics 


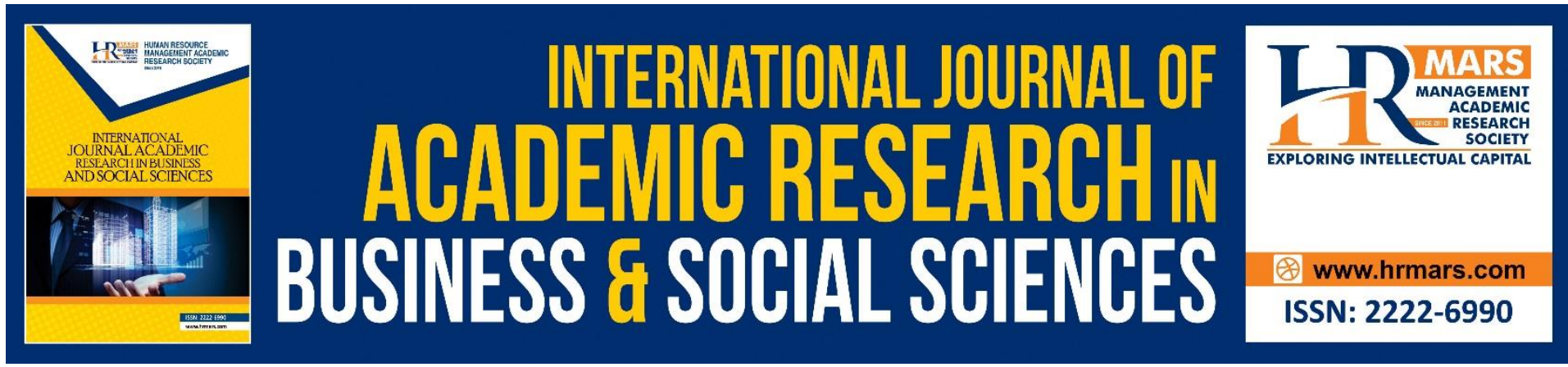

\title{
Igenerations' Intention to become Entrepreneur: Determinants in Malaysia
}

\author{
Melissa Wee ${ }^{1}$, Nur Rabiatul Adawiyah², Mohd Zaki Sadik ${ }^{3}$, Nor \\ Lelawati Jamaluddin ${ }^{4}$ \\ 1,3Universiti Teknologi MARA, Cawangan Melaka, ${ }^{4}$ Universiti Teknologi MARA, Cawangan \\ Selangor
}

\begin{abstract}
The purpose of the research is to examine determinants that influence entrepreneurial intention among iGeneration in Malaysia. This study shall investigate the relationship between perceived education supports, perceived informal network, perceived formal network, and proactive personality toward entrepreneurial intention. The method that have been used in this study was a causal research or hypothesis testing in the experiment, and non-probability sampling was used and to be more precise, judgmental purposive sampling. Primary data was collected through questionnaires that have been distributed among undergraduates in Malaysia. The data has been collected and analyze among 183 respondents by using the Statistical Package for Social Science (SPSS). All the independent variables were found to be significantly positive with entrepreneurial intention except for perceived formal network.
\end{abstract}

Keywords: Perceived Education Supports, Perceived Informal Network, Perceived Formal Network, Proactive Personality, Entrepreneurial Intention

\section{Introduction}

Entrepreneurship is also the most desirable career path for youngsters, with $17.4 \%$ of those who do not work choosing to build a company as their ambition (Oliver, 2019). Entrepreneurs are basically referred to anyone who have undertaking any activities that is associated with the promotion of entrepreneurship either through personal level or nationwide (Nikolic et al., 2017). Meanwhile entrepreneurial intention can be considered as one of the best medium of planned behaviour (Li \& Wu, 2019). In addition, recent developments in digital technologies have had an impact on jobs and education that will led to job losses, economic inequalities and, shifts in work patterns and are posing new obstacles for labour market participants. It is therefore crucial to decide how to promote the creation of a growing number of businesses and how to allow enterprises to develop rapidly and generate considerable value. Thereupon, it is important to develop creativity, and improved their self-realization to be develop business (Gubik \& Farkas, 2020).

Previous research also has suggested young people among generations should be studied and analyzed for entrepreneurship activities (Mahmood et al., 2019). He also said that new 
generation students are more likely to achieve success in business world because they are usually associated with a higher risk of failure and focus on real issues, wide and varied solutions, networking, and removing barriers. This research also are mainly focusing on undergraduates among iGeneration which has been named with many different terms such as Post Millennial, Generation Z, Gen Tech and many more in order to fit it with the world that they are born with which is the era where they are easily connected through technology (Dolot, 2018). Studies conducted by Turner \& Turner (2018) have concluded that this generation is best known as "Digital Natives" as they are always taking after technological advances. iGeneration has become the largest generation in 2019, consisting of $32 \%$ of the world's population, making up 2.47 billion of the 7.7 billion people on Earth (Boomers \& Genzers, 2020). Research indicates that iGeneration is characterized as being very ambitious and striving for a successful career. They also supported their statement by stating that a study conducted by Nielsen has indicated that about 54 percent of this generation intended to begin their own business. The business desires have been driven by the idea of gaining more power, loans-free, a meaningful life and being useful to the earth for their life (Schroeder, 2020).

Unemployment has been a very critical issue nowadays for every country, particularly in a developing country with a significant number of populations. High unemployment indicates that labour capital are not being utilized effectively. The global unemployment rate is described as the percent of the overall labour force unemployed. It's generally recognized as a key measure of a country's labour market performance (Toh, 2018). As a closely monitored economic indicator, the unemployment rate has attracted a lot of media attention, particularly during recessions and challenging economic times. In March 2020, as stated by Department of Statistic Malaysia, the unemployment rate in Malaysia have rose drastically from 3.4 percent in the same month from previous year in 2019 to 3.9 percent in March 2020. The high unemployment rate in March 2020 has been identified due to MCO on the labour market (Mahidin, 2020).

Thus, unemployment issues among graduates, has become a serious concern. Malaysia Research also has found that unemployment rate among youth will needed a highly serious attention (Seng, 2018). Seng also stated that they have recorded that six out of ten of those unemployed are below 24 years old. Hence, the researcher wants to determined factors that trigger iGenerations' intention to be an entrepreneur which the objectives of this study are:

- To determine whether there are any positive relationship between perceived educational supports, perceived informal support, perceived formal network and proactive personality towards entrepreneurial intention.

\section{Literature Review}

\section{Entrepreneurial Intention}

According to Silveira et al. (2017), entrepreneurial intention is the most important key element in the process of developing new businesses. There are also many definitions regarding entrepreneurial intention from several studies. Sindha Neelam (2014) also agreed in their studies by stating that entrepreneurial intention is basically to seek for knowledge to achieve the goal of the development of a new business. Entrepreneurial intentions may also be described as a goal to own a company or become self-employed. Entrepreneurship goals are often known to be individual preferences that may contribute to the development of 
projects (Esfandiar et al., 2019). Scientifically, intention has been proven to be the best in some studies as the measure of entrepreneurial activities that have been done throughout the last few years (Mohammed, 2019). In the simpler terms, intention can predict the actions and attitudes of someone. As conclusion intention plays a significant role as a bridge between the creation of a business venture and macroeconomic influence.

\section{Perceived Education Support}

The researchers have found that the influence of education, support has been identified as one of the key factors that help young people to realize and promote an entrepreneurial attitude in themselves (Wang, 2014). Academic institutions can promote entrepreneurship in many ways, but it is crucial to measure from students' view regarding the amount of support and information they receive to know the effectiveness of such support and its effect on students. There is also an evidence on the importance of entrepreneurship toward economy growth where there is a general belief, that there is a connection between delivering of entrepreneurial education and promoting the economic development and enhancing of employment opportunities (Saeed et al., 2015). The growth of education support is prominent as it has drawn the government attention around the world. Education support are known for their economic development and technology development mechanisms (Soria-Barreto et al., 2017). In addition, a growing number of incentives have seen institutions as seedbeds for the promotion of entrepreneurial intent and community. Educational institutions will play a significant role in recognizing and enhancing the entrepreneurial characteristics and motivations of students and making them successful in establishing their own businesses in the future. According to Mohammed (2019), students who are engaged in entrepreneurship education along with industry specialty can increase the effective support and role of institutions in helping to develop the student's motivations to become an entrepreneur. Structured education or information with a clear purpose has been established to improve student entrepreneurial productivity. This education support also will assist in the growth of better approach toward entrepreneurship among students and will also allow them to gain information and abilities that can enable them to deal with challenging situations in the future (Moraes et al., 2018).

\section{Perceived Informal Network}

Several researches have also examined the view and effect of attitudes, behaviours and resources that have led to the success of entrepreneurship. One of the variables which has been identified is through the social circle and networks around entrepreneurs' life. According to Escandon-Barbosa et al. (2019) motivating and promoting entrepreneurship has become a core aspect of economic growth in nations around the world. They also said that the entrepreneurial spirit of students is shaped by role models. They point out that when family members' beliefs are cautious and sensitive to uncertain and risky projects, they try to prevent their kids from engaging in entrepreneurship activities. However, if family are openminded and have a direct and positive influence toward business, they will encourage their children to undergo the process of entrepreneurship and to take part in any entrepreneurship activities. Furthermore, the relationship between family's members in a growing business can provides a solid link in a business network.

Friends and family members are part of the best network in individuals' lives who will provide emotional and financial support through various phases. They will also gain support, 
knowledge and connect directly to distribution channels through their social connections. They are also will directly connected to individuals and organizations engaging with each other, and these connections can improve the accessibility of resources to support a new venture. In their early process of becoming an entrepreneur, they will seek not only facilities, resources, and money, but also advice, guidance, information, and support and encouragement. (Kanyan \& Kasuma (2020) also believe that the presence of family members during the early stages of the creation of the business is vital and thus needs more attention in the area of entrepreneurship. In other words, families provide support, both professionally and non-professionally, which eventually influences the behaviour of an entrepreneur. Informal networks also can have a major effect on the entrepreneurial intentions among university students.

\section{Perceived Formal Network}

On the other hand, the formal network also affects the intention of the entrepreneur. Before Persons become engaged in entrepreneurship, they might have to consider how such a network would work (Kanyan \& Kasuma, 2020). They will be assisted by such parties as banks and organizations and forms to gain access to the resources they need. When entrepreneurs start their new business, they appear to have a very little idea of how to conduct business. Therefore, they need help and support from an organization that is already functional. Availability to capital is a common obstacle for potential entrepreneurs in emerging economies such as Malaysia. Studies have claimed that the lack of access to financial resources is considered a main obstacle to several possible entrepreneurs. Turulja et al. (2020) also explain in their study that formal networks are connected into a various group of young people within the market economy to which formal connections are established. They also cited in their studies that the formal network consists of professional consultants, enterprise-related organizations, consumer and supplier networks, and other entrepreneurs.

Formal institutions and a regulatory system to encourage entrepreneurial activities are one of the main components of the entrepreneurship process. Regulatory and other government assistance are an important part of a larger formal support that deserves to be specifically evaluated. Studies have also reviewed that legal barriers to entrepreneurship can be recognized as one of the significant structural obstacles. When the general view of structural barriers is negative, young entrepreneurs may be less eager to start their business. Nevertheless, if it shows a positive view of the policy and legal conditions regulating entrepreneurship it can be resulted in a higher entrepreneurial intention. Entrepreneurs need knowledge, money, skills and labour to start their business operations. Although they keep each of these resources on their own, they also need others support for their resources by using other networks. Formal networks will provide a number of useful qualities for entrepreneurs (Veldhuis et al., 2013). Before persons become engaged in entrepreneurship, they might have to consider how formal networks involving such groups as banks and organizations, government agencies and business associations will help them receive access to the resources they need (Effect of Social Network Ties in Entrepreneurial Opportunity Recognition \& Moderation Effect of SE, 2016). They will be helped by not only by their direct contacts, but also by numerous potential relationships with lawyers, finance companies, investors, accountants, professional consultants, scholars, consumers, suppliers or professional associations who could assist them to be a successful entrepreneur and guide them transform their ideas into profits. 


\section{Proactive Personality}

Personality has been playing one of the most significant roles in the development and growth of the business. Previous research has defined proactive personality as a constant in ability to alter according to their surroundings, which describes people by their behavior and actions that will be affected by their environment (Hou et al., 2019). They also said that proactive personality, however, has been effective in estimating sales growth above and beyond self efficacy. In addition, students are susceptible to the influence of colleagues who may have similar background resources. Proactivity refers to an individual's effective efforts to adapt to changes in his or her surroundings. Proactive personality has therefore been defined as a pattern of attitude that describes diversity of people in the extent to which they take action to improve their environment. Individuals with proactive personalities usually take the action to influence and even greatly change their surroundings (Miao, 2015). In other words, having a proactive personality can assist in helping release situational pressures, identify potential opportunities for advantage, take proactive actions, and thus influence the surroundings to create more valuable differences (Mahmood et al., 2019).

Further explanations of proactive personality have included a willingness to concentrate on self-development, to act more openly, to work constantly to regulate one's environment, and to obtain more knowledge (Ahmed \& Zumrawi, 2015). In addition, people with proactive personalities appear to set high expectations and utilize all existing resources to achieve those goals. Studies show that proactive personality is a uniquely different component of personality trait which is a popular indicator of a variety of useful work outcomes. They also said that being proactive is like acknowledging responsibility for one's actions in the present, past and future, and putting in the effort to make it better, and recognizing that they have the ability to make good decisions that will improve the negative. Self-awareness is the secret to being successful, and if they are not cautious of the negative responses surrounding you, it would be difficult for them to transform them into productive behaviour and attitude (Ahmed \& Zumrawi, 2015).

\section{Research Model and Hypotheses}

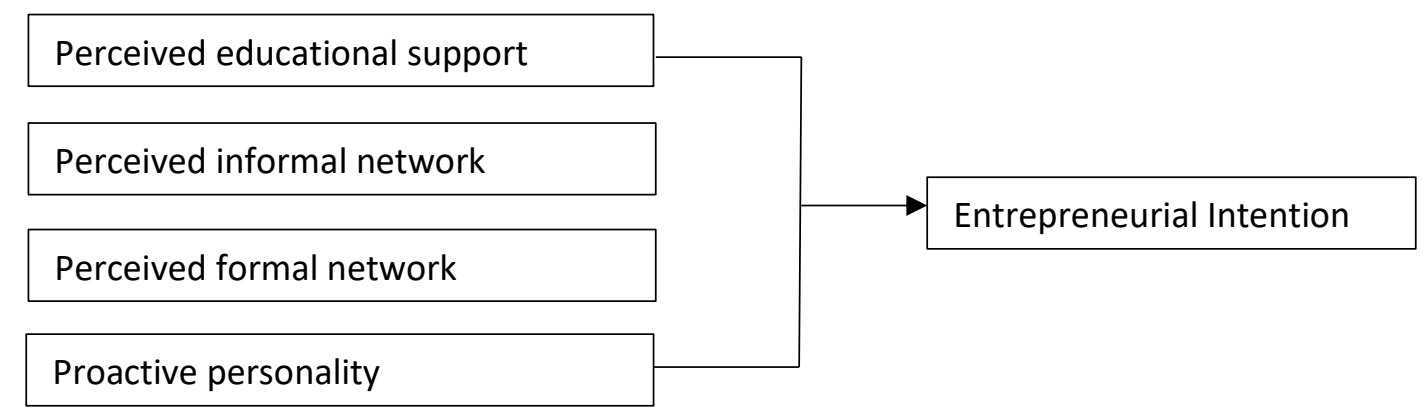

IV

DV

Figure 1: Theoretical Framework

H1: Perceived educational support has positive relationship with entrepreneurial intention.

$\mathrm{H} 2$ : Perceived informal network has positive relationship with entrepreneurial intention H3: Perceived formal network has positive relationship with entrepreneurial intention.

$\mathrm{H} 4$ : Proactive personality has positive relationship with entrepreneurial intention. 


\section{Methodology}

Respondents of this study are among undergraduates iGeneration which are born within the year 1995 until 1999. A total of 183 respondents answered the questionnaires through a purposive judgement sampling whereby participants are chosen for research purposes with the aim that each respondent can have unique and valuable knowledge and information for the importance of the analysis (Etikan, 2016). In order to ensure the validity of the choice of respondent two criteria were determined for this study which are 1) Must be an undergraduate from any public or private higher education institution 2) Must be born between the year 1995 until 1999. In terms of the distribution of gender, most of the respondents were female, $70.4 \%$ and all (100\%) of them are single. As for education level, majority of the respondents were Degree holders (62.9\%) and studied in public universities (73.1\%). Most of the respondents have been involved with at least ONCE in business (61.8\%) and $29.6 \%$ came from families with business background. Data was collected using a structured questionnaire which contains 6 sections which are Section A for Demographic Profile, Section B FOR Entrepreneurial Intention and Section C to F are the Perceived Educational Support, Perceived Informal Network, Perceived Formal Network and Proactive Personality. The questionnaire was adopted from a measurement developed by Tassawa (2019), Wibowo et al., (2019) and Delle \& Amadu (2015) that used 5-point Likert-scale. All the dimensions are reliable -0.947 for entrepreneurial intention, perceived education support with 0.884 , perceived informal network with 0.832 , perceived formal network with 0.798 and lastly proactive personality with 0.887 which indicates that all are reliable. The $\mathrm{R}^{2}$ for this study is 0.575 which indicate that $57.5 \%$ of the variation of dependent variable are an interpretation by the independent variables. In analyzing the research model, this study used the Statistical Package for the Social Sciences software (SPSS) to run the Multiple Regression analysis and test the hypotheses to discover the relationship between independent variables and dependent variable of this study.

Assessment of Hypotheses using structural model

Table 1 Hypothesis Testing

\begin{tabular}{|c|c|c|c|c|c|c|}
\hline Hyp & Relationship & Std Beta & $\begin{array}{c}\text { Std } \\
\text { Error }\end{array}$ & t-value & Sig & Decision \\
\hline H1 & $\begin{array}{c}\text { Perceived Education } \\
\text { Support-Entrepreneurial } \\
\text { Intention }\end{array}$ & 0.320 & $\begin{array}{c}0.06 \\
7\end{array}$ & 4.796 & 0.000 & Supported \\
\hline H2 & $\begin{array}{c}\text { Perceived Informal } \\
\text { Network-Entrepreneurial } \\
\text { Intention }\end{array}$ & 0.164 & $\begin{array}{c}0.07 \\
6\end{array}$ & 2.157 & 0.032 & Supported \\
\hline H3 & $\begin{array}{c}\text { Perceived Formal } \\
\text { Network-Entrepreneurial } \\
\text { Intention }\end{array}$ & 0.127 & $\begin{array}{c}0.08 \\
6\end{array}$ & 1.483 & 0.140 & Sot \\
\hline $\mathrm{H} 4$ & $\begin{array}{c}\text { Proactive Personality- } \\
\text { Entrepreneurial } \\
\text { Intention }\end{array}$ & 0.590 & $\begin{array}{c}0.08 \\
7\end{array}$ & 6.780 & 0.000 & Supported \\
\hline
\end{tabular}

\section{Discussion}

Kusumawardhany \& Dwiarta (2020) have agreed that there is a direct connection between perceived education support and the entrepreneurial intention. As the academic institution 
have surrounding and facilities that will offer essentials in-depth knowledge and understanding of entrepreneurship. In addition, the presence of entrepreneurship courses also is intended to improve students' experiences and knowledge into the field of business and enable them to be actively active in the world of entrepreneurship as competitive young entrepreneurs so that they can contribute to developing the economy. Meanwhile there is positive relationship between perceived informal network and entrepreneurial intention which is consistent with Bignotti \& Le Roux (2016); Kanyan \& Kasuma (2020). Kanyan and Kasuma also stated in their study that informal network depends heavily on close friends, family members and mutual networks to collect valuable data at an early stage of business growth as family influences will contribute toward development of knowledge, skills and networks are required in order for entrepreneurs to be successful in their business projects. As for the third hypothesis, according to Turulja et al. (2020), no support will be found for the formal network support due to economic situations and weak ties with formal network. Formal network also requires a strong tie that come with great loyalty for them to share vital information (Dodd \& Keles, 2015). From the background information that have been collected from the respondents it can be seen that $70.4 \%$ of the respondents come from female population it has been proposed by Klyver \& Grant (2010) that women would be weakened in formal network because of the absence of resources and social networks compared to men. Women also usually tend to have business networks that are fewer and less diverse than men (European Commission \& OECD, 2017). Lastly, Delle \& Amadu (2015) has agreed in their study that proactive personality is significant toward entrepreneurial intention. it has shown that more than half of it came from female respondents in which can affect the result as Sidratulmunthah et al. (2018) has confirmed that proactive personality is a significant factor in the development toward female's enterprises where there have more ambitious to create a business

\section{Conclusion}

From this study, there is a significant impact of perceived education support, perceived informal network, and proactive personality toward entrepreneurial intention. Through this, the higher education system can continue to provide and improved by identifying, researching, and implementing different ways of education, learning and development. They also could consider their education more attractive and realistic by combining the theory of economic and business beliefs with real-life so that they can be prepared with real life. Technology has claimed its dominance in today's world culture. Higher learning institutions can improve their students' careers by bringing more technological concepts into teaching methods. The aim to educate creative ways in which they can use technology to develop, connect, market, and promote their future business. While for the formal network support there are still lack of perceived formal network support toward entrepreneurial intention. From this formal network support, it can be improving by providing help toward students in launching their business. Business premises can work in partnership with students to help them to conduct research, obtain financing and create their own business. At the same time formal network also can provide business coaching services regarding small business towards those who are interested. This is where they can provide the right strategy to develop a business for a young entrepreneur. Overall this study adds more understandings on the iGenerations' drive to go for independent career specifically entrepreneurship. Higher education should emphasize more on creating formal network opportunities for their graduates in order to support their entrepreneurial intention. 


\section{Corresponding Author}

Melissa Wee

Universiti Teknologi MARA, Malacca, Malaysia

Email: nurmelissa@uitm.edu.my

\section{References}

Abbasianchavari, A., \& Moritz, A. (2020). The impact of role models on entrepreneurial intentions and behavior: a review of the literature. In Management Review Quarterly (Issue 0123456789). Springer International Publishing. https://doi.org/10.1007/s11301019-00179-0

Ahmed, S. A. I., \& Zumrawi, M. (2015). The Importance of Proactive Personality in Life Success. Ministry of Health Journal, January 2015.

Amos, A. O., Oluseye, O. O., \& Bosede, A. A. (2015). Influence of Contextual Factors on Entrepreneurial Intention of University Influence of Contextual Factors on Entrepreneurial Intention of University Students: The Nigerian Experience. 2015(October). https://doi.org/10.5171/2015.750622

Bazan, C., Shaikh, A., Frederick, S., Amjad, A., Yap, S., Finn, C., \& Rayner, J. (2019). Effect of memorial university's environment \& support system in shaping entrepreneurial intention of students. In Journal of Entrepreneurship Education (Vol. 22, Issue 1).

Bielik, P., Horsk2, E., \& Ubreziova, A. (2011). Journal of Economics and Business. Economics and Business, 16(110), 853-862.

https://doi.org/10.31014/aior.1992.03.02.241

Bignotti, A., \& Le Roux, I. (2016). Unravelling the conundrum of entrepreneurial intentions, entrepreneurship education, and entrepreneurial characteristics. Acta Commercii, 16(1). https://doi.org/10.4102/ac.v16i1.352

Toh, B. (2018). Unemployment a serious issue in Malaysia - MIER. 1-8. http://www.theedgemarkets.com/article/unemployment-serious-issue-malaysia--mier

Boston University School of Public Health. (2019). Behavioral Change Models : The Theory of Planned Behavior. 2-3. http://sphweb.bumc.bu.edu/otlt/MPHModules/SB/BehavioralChangeTheories/BehavioralChangeTheories3.html

Bouey, J. (2020). Assessment of COVID-19's Impact on Small and Medium-Sized Enterprises: Implications from China. Assessment of COVID-19's Impact on Small and Medium-Sized Enterprises: Implications from China. https://doi.org/10.7249/ct524

Buana, H. (2020). THE ANALYSIS OF SOCIAL ENTREPRENEURIAL INTENTION AMONG YOUNG GENERATION ( STUDY CASE : STUDENT OF FACULTY OF BUSINESS PRESIDENT UNIVERSITY ). 5(1), 34-49.

Cardella, G. M., Hernández-Sánchez, B. R., \& Sánchez García, J. C. (2020). Entrepreneurship and Family Role: A Systematic Review of a Growing Research. Frontiers in Psychology, 10, 1-28. https://doi.org/10.3389/fpsyg.2019.02939

Delle, E., \& Amadu, I. M. (2015). Proactive Personality and Entrepreneurial Leadership. August.

Dodd, S. D., \& Keles, J. (2015). Expanding the networks of disadvantaged entrepreneurs. OECD (Organisation for Economic Co-Operation and Development), 1-46. https://www.oecd.org

Effect of Social Network Ties in Entrepreneurial Opportunity Recognition \& moderation effect of SE. (2016). http://www.thehindu.com/news/national/census-reveals-only-marginal- 
increase-in-the-

Ensari, M. S. (2017). A study on the differences of entrepreneurship potential among generations. Pressacademia, 4(1), 52-62.

https://doi.org/10.17261/pressacademia.2017.370

Escandon-Barbosa, D., Urbano-Pulido, D., \& Hurtado-Ayala, A. (2019). Exploring the relationship between formal and informal institutions, social capital, and entrepreneurial activity in developing and developed countries. Sustainability (Switzerland), 11(2). https://doi.org/10.3390/su11020550

Esfandiar, K., Sharifi-Tehrani, M., Pratt, S., \& Altinay, L. (2019). Understanding entrepreneurial intentions: A developed integrated structural model approach. Journal of Business Research, 94(October), 172-182. https://doi.org/10.1016/j.jbusres.2017.10.045

Etikan, I. (2016). Comparison of Convenience Sampling and Purposive Sampling. American Journal of Theoretical and Applied Statistics, 5(1), 1. https://doi.org/10.11648/j.ajtas.20160501.11

European Commission, \& OECD. (2017). Policy Brief on Women's Entrepreneurship. https://doi.org/10.2767/50209

Examples of Causal Research ( Explanatory Research) Advantages of Causal ( Explanatory Research ) Disadvantages of Causal ( Explanatory Research ). (2014).

Fini, R., Grimaldi, R., Marzocchi, G. L., \& Sobrero, M. (2009). The Foundation of Entrepreneurial Intention. Summer Conference 2009 on Copenhagen Business School, January, 1-36.

For, O., \& To, R. A. (2018). Isis policy brief. 17-19.

Fuentelsaz, L., González, C., \& Maicas, J. P. (2019). Formal institutions and opportunity entrepreneurship. The contingent role of informal institutions. BRQ Business Research Quarterly, 22(1), 5-24. https://doi.org/10.1016/j.brq.2018.06.002

Gubik, A. S., \& Farkas, S. (2020). Entrepreneurial Intention in the Visegrad Countries. Danube, 10(4), 347-368. https://doi.org/10.2478/danb-2019-0018

Hou, F., Su, Y., Lu, M., \& Qi, M. (2019). Model of the entrepreneurial intention of university students in the Pearl River Delta of China. Frontiers in Psychology, 10(APR). https://doi.org/10.3389/fpsyg.2019.00916

Hu, R., Wang, L., Zhang, W., \& Bin, P. (2018). Creativity, proactive personality, and entrepreneurial intention: The role of entrepreneurial alertness. Frontiers in Psychology, 9(JUN), 1-10. https://doi.org/10.3389/fpsyg.2018.00951

Issn, K. (2014). Kasbit business journal (kbj). 1609(1), 1-109.

Ivanović-Djukić, M., Lepojević, V., Stefanović, S., van Stel, A., \& Petrović, J. (2018). Contribution of Entrepreneurship to Economic Growth: A Comparative Analysis of SouthEast Transition and Developed European Countries. International Review of Entrepreneurship, 16(2), 257276.http://ezproxy.hwrberlin.de:2048/login?url=http://search.ebscohost.com/login.as px?direct=true \&db=ent\&AN=130879502\&lang=de\&site=eds-live\&scope=site

Kadir, M. B. A., Salim, M., \& Kamarudin, H. (2012). The Relationship Between Educational Support and Entrepreneurial Intentions in Malaysian Higher Learning Institution. Procedia - Social and Behavioral Sciences, 69(Iceepsy), 2164-2173. https://doi.org/10.1016/j.sbspro.2012.12.182

Kale, A. (2013). Chapter 7 Descriptive Analysis. Shodhganga, 193-231. https://doi.org/10.1016/B978-1-4377-0651-2.10007-4

Kan, M. P. H., Fabrigar, L. R., \& Fishbein, M. (2017). Encyclopedia of Personality and Individual 
Differences. Encyclopedia of Personality and Individual Differences, 1-8. https://doi.org/10.1007/978-3-319-28099-8

Kanyan, A., \& Kasuma, J. (2020). Relationship Between Informal and Formal Network Towards Entrepreneurial Intention Among Undergraduate at Public University. Journal of Entrepreneurship and Business, 8(1), 59-70. https://doi.org/10.17687/jeb.0801.05

Klyver, K., \& Grant, S. (2010). Gender differences in entrepreneurial networking and participation. International Journal of Gender and Entrepreneurship, 2(3), 213-227. https://doi.org/10.1108/17566261011079215

Kusumawardhany, P. A., \& Dwiarta, I. M. B. (2020). Entrepreneurial Intention Among Millennial Generation: Personal Attitude, Educational Support, and Social Media. 115(Insyma), 63-68. https://doi.org/10.2991/aebmr.k.200127.013

Li, L., \& Wu, D. (2019). Entrepreneurial education and students' entrepreneurial intention: does team cooperation matter? Journal of Global Entrepreneurship Research, 9(1). https://doi.org/10.1186/s40497-019-0157-3

Mahidin, M. U. (2020). Key Statistics of Labour Force in Malaysia, March 2020. Department of Statistics Malaysia, MAY, 5-9. https://doi.org/10.1017/СBO9781107415324.004

Mahmood, T. M. A. T., Al Mamun, A., Bin Ahmad, G., \& Ibrahim, M. D. (2019). Predicting entrepreneurial intentions and pre-start-up behaviour among Asnaf millennials. Sustainability (Switzerland), 11(18), 1-26. https://doi.org/10.3390/su11184939

Merriman, M. (2015). Rise of Gen Z: new challenge for retailers. Ernst \& Young LLP, 1-12. http://www.ey.com/Publication/vwLUAssets/EY-rise-of-gen-znew-challenge-forretailers/\$FILE/EY-rise-of-gen-znew-challenge-for-retailers.pdf

Miao, C. (2015). VCU Scholars Compass Individual Traits and Entrepreneurial Intentions : The Mediating Role of Entrepreneurial Self-Efficacy and Need for Cognition.

Miller, A. C., \& Mills, B. (2019). 'If They Don't Care, I Don't Care': Millennial and Generation Z Students and the Impact of Faculty Caring. Journal of the Scholarship of Teaching and Learning, 19(4), 78-89. https://doi.org/10.14434/josotl.v19i4.24167

Minitab. (2016). Interpret the key results for Correlation. 1-9. http://support.minitab.com/en-us/minitab-express/1/help-and-how-to/modelingstatistics/regression/how-to/correlation/interpret-the-results/

Mohammed, A. Q. (2019). Measuring students entrepreneurial intentions: The study of al Dhafra region, Abu Dhabi, UAE. International Journal of Entrepreneurship, 23(3), 1-10.

Molino, M., Dolce, V., Cortese, C. G., \& Ghislieri, C. (2018). Personality and social support as determinants of entrepreneurial intention. Gender differences in Italy. PLoS ONE, 13(6), 1-19. https://doi.org/10.1371/journal.pone.0199924

Moraes, G. H. S. M. de, lizuka, E. S., \& Pedro, M. (2018). Effects of Entrepreneurial Characteristics and University Environment on Entrepreneurial Intention. Revista de Administração Contemporânea, 22(2), 226-248. https://doi.org/10.1590/19827849rac2018170133

Mu, A. (2019). 済無No Title No Title. Journal of Chemical Information and Modeling, 53(9), 1689-1699. https://doi.org/10.1017/CBO9781107415324.004

Nathans, S. (2012). Prologue: A Secret Striving. To Free a Family, August 2015, 1-8. https://doi.org/10.4159/harvard.9780674063297.c1

Nikolic, M., Cockalo, D., Terek, E., Bozic, S., \& Nastasic, A. (2017). The impact of life values on entrepreneurial intentions of students in Serbia. Journal of Engineering Management and Competitiveness, 7(1), 28-34. https://doi.org/10.5937/jemc1701028n

Oliver, J. (2019). 済無No Title No Title. Hilos Tensados, 1, 1-476. 
https://doi.org/10.1017/CBO9781107415324.004

Papadopoulos, V., \& Giovanis, D. G. (2018). Reliability analysis. Mathematical Engineering, 9783319645278, 71-98. https://doi.org/10.1007/978-3-319-64528-5_4

Park, C. (2017). A study on effect of entrepreneurship on entrepreneurial intention. Asia Pacific Journal of Innovation and Entrepreneurship, 11(2), 159-170. https://doi.org/10.1108/apjie-08-2017-024

Parvaneh Gelard. (2011). Impact of some contextual factors on entrepreneurial intention of university students. African Journal of Business Management, 5(26), 10707-10717. https://doi.org/10.5897/ajbm10.891

Peng, Z., Lu, G., \& Kang, H. (2012). Entrepreneurial Intentions and Its Influencing Factors: A Survey of the University Students in Xi'an China. Creative Education, 03(08), 95-100. https://doi.org/10.4236/ce.2012.38b021

Prieto, L. C. (2011). The influence of proactive personality on social entrepreneurial intentions among African-American and hispanic undergraduate students: The moderating role of hope. Academy of Entrepreneurship Journal, 17(2), 77-96.

Ranjan, A. (2013). The role of entrepreneurship in economic development. Global Entrepreneurship and Development Index 2013, 4(6), 53-71. https://doi.org/10.4337/9781782540427.00010

Sabah, S. (2016). Entrepreneurial Intention: Theory of Planned Behaviour and the Moderation Effect of Start-Up Experience. Entrepreneurship - Practice-Oriented Perspectives. https://doi.org/10.5772/65640

Saeed, S., Yousafzai, S. Y., Yani-De-Soriano, M., \& Muffatto, M. (2015). The Role of Perceived University Support in the Formation of Students' Entrepreneurial Intention. Journal of Small Business Management, 53(4), 1127-1145. https://doi.org/10.1111/jsbm.12090

Sales, C. (2014). Get Started Today. 1-3.

Schroth, H. (2019). Are you ready for gen $Z$ in the workplace? California Management Review, 61(3), 5-18. https://doi.org/10.1177/0008125619841006

Seng, L. C. (2018). Malaysia Public Universities' Graduate Employability Policies : An Analysis of First Degree Graduates Unemployment and Underemployment Issues. International Journal of Social Science and Humanities Research, 6(4), 480-489. https://doi.org/10.5281/zenodo.2589702

Shah, A. U. M., Safri, S. N. A., Thevadas, R., Noordin, N. K., Rahman, A. A., Sekawi, Z., Ideris, A., \& Sultan, M. T. H. (2020). COVID-19 outbreak in Malaysia: Actions taken by the Malaysian government. International Journal of Infectious Diseases, 97, 108-116. https://doi.org/10.1016/j.ijid.2020.05.093

Sharma, L., \& Madan, P. (2014). Effect of individual factors on youth entrepreneurship - a study of Uttarakhand state, India. Journal of Global Entrepreneurship Research, 2(1), 3. https://doi.org/10.1186/2251-7316-2-3

Sidratulmunthah, Hussain, S., \& Imran Malik, M. (2018). Towards nurturing the entrepreneurial intentions of neglected female business students of Pakistan through proactive personality, self-efficacy and university support factors. Asia Pacific Journal of Innovation and Entrepreneurship, 12(3), 363-378. https://doi.org/10.1108/apjie-032018-0015

Silveira, A., Ferreira, C. C., Silvente, G. A., \& Carneiro da Cunha, J. A. (2017). Factors and Approaches of Entrepreneurial Intention. Revista de Empreendedorismo e Gestão de Pequenas Empresas, 6(2), 263-290. https://doi.org/10.14211/regepe.v6i2.532

Sindha Neelam. (2014). Review of literature 2 . Review of literature. Amjad 2011, 49-58. 
Soria-Barreto, K., Honores-Marin, G., Gutiérrez-Zepeda, P., \& Gutiérrez-Rodríguez, J. (2017). Prior exposure and educational environment towards entrepreneurial intention. Journal of Technology Management and Innovation, 12(2), 45-58. https://doi.org/10.4067/S0718-27242017000200006

Tassawa, C. (2019). A structural model for predicting entrepreneurial intention of university students. Humanities, Arts and Social Sciences Studies, 19(2), 362-386. https://doi.org/10.14456/hasss.2019.11

Turulja, L., Veselinovic, L., Agic, E., \& Pasic-Mesihovic, A. (2020). Entrepreneurial intention of students in Bosnia and Herzegovina: what type of support matters? Economic ResearchEkonomska Istrazivanja , 0(0), 1-20. https://doi.org/10.1080/1331677X.2020.1730216

UCLA. (2020). Regression Analysis | Spss Annotated Output. 2, 1-9. https://stats.idre.ucla.edu/spss/output/regression-analysis/

Veldhuis, S., Wubben, E. F. M., \& Bijman, W. J. J. (2013). Informal and formal networks: The development of informal and formal networks for internationalization of Dutch food SMEs. August, 1-52.

Wang, C. K. (2014). Entrepreneurial Intentions and Tertiary Education *. May.

Wibowo, S. F., Purwana, D., Wibowo, A., \& Saptono, A. (2019). Determinants of entrepreneurial intention among millennial generation in emerging countries. International Journal of Entrepreneurship, 23(2), 1-10.

Wong, R. L. M., Lai, K. H. W., Huang, S. S., Jonas, J. B., \& Lam, D. S. C. (2020). COVID-19 Pandemic: Ways Forward. Asia-Pacific Journal of Ophthalmology (Philadelphia, Pa.), 9(2), 59-60. https://doi.org/10.1097/APO.0000000000000283

Yurtkoru, E. S., Kuşcu, Z. K., \& Doğanay, A. (2014). Exploring the Antecedents of Entrepreneurial Intention on Turkish University Students. Procedia - Social and Behavioral Sciences, 150, 841-850. https://doi.org/10.1016/j.sbspro.2014.09.093

Zhang, B. L. (2020). More than one in six young people have stopped working since the onset of the coronavirus pandemic while those who remain employed have seen their working hours cut by 23 percent, according to the latest International Labor Organization (ILO) data. 1-11. 